\title{
The Main Ion Concentrations in Surface Soil Layer in Nam Dinh Province of the Red River Delta, Northern Vietnam
}

\author{
DINH Hung Thai* and HARUYAMA Shigeko** \\ * Graduate Student, The University of Tokyo, Kashiwa, Chiba 277-8563, Japan \\ ** Graduate School of Frontier Sciences, The University of Tokyo, \\ Kashiwa, Chiba 277-8563, Japan
}

\begin{abstract}
This study aims to clarify the main ion concentrations in paddy field surface soil from 0 to $100 \mathrm{~cm}$ in depth along the coast of the Red River Delta, Northern Vi etnam, represented by Nam Dinh Province. There is a relation between total dissolved solid (TDS) and $\mathrm{Na}^{+}$concentration. $\mathrm{Na}^{+}$and $\mathrm{Cl}^{-}$concentrations in paddy fields increase gradually and the abundance of $\mathrm{Cl}^{-}$ concentration in soil proclaims the influence of seawater intrusion. Washing is reported to reduce the high salinity in the cultivation-layer soil of paddy fields. Furthermore, the impact of seawater intrusion on soil salinity of coastal paddy fields has been considered. The top soil layer of coastal salt-affected paddy fields has the highest sodium absorption ratio (SAR) values, and shows the strongest salinity influence in both the flood season and the dry season. Soil samples near the Day River mouth have high SAR values with considerable $\mathrm{Na}^{+}$concentrations in the dry season. The exchange selectivity between $\mathrm{Ca}^{2+}, \mathrm{Mg}^{2+}$ and $\mathrm{Na}^{+}$has also been studied by considering changes in the SAR under different conditions of soil composition and land cover. In coastal agricultural land, the SAR in the surface soil layer can be used to evaluate the influence of salinity. The SAR in cultivated soil is used to assess the influence of salinity problems on the paddy field.
\end{abstract}

Key words: The Red River Delta, coastal agricultural land, ion concentrations, TDS (Total Dissolved Solid), SAR (Sodium Absorption Ratio)

\section{Introduction}

The Red River Delta is located in Northern Vietnam. Its agricultural and ecological conditions limit the Red River Delta to being used mainly for paddy cultivation of rice. The delta is approximately $12,500 \mathrm{~km}^{2}$, with a coastline more than $160 \mathrm{~km}$ in length and seven river mouths (Le 1997).

The Red River Delta's coastal agricultural area that belongs to Nam Dinh Province (Figure 1) is mainly paddy field. In Nam Dinh Province, maximum temperature reaches its lowest value $\left(10.4^{\circ} \mathrm{C}\right)$ in March. The total of sunshine hours is very low, from 1.2 to 1.5 hour per day in the dry season from January to March (Figure 2). Furthermore, river discharge, described in terms of the average value of the water level in the Dao River, is insufficient, and rainfall is also rare (Figure 3).

The coastal area is affected by erosion due to typhoons and seawater intrusion in the dry sea- son. Typhoons and tropical storms are frequent between July and October, and have increased in recent years, causing strong coastline erosion (Matsumoto et al. 2001). Coastal erosion has been reported along the coastline between the Red River mouth and the Ninh Co River mouth (Haruyama and Vu 2002). On the other hand, the deposition land located at the mouths of the Red River, the Ninh Co River and the Day River receives sediment continuously by flow transportation. It is reported that the area surrounded by the Red River and Ninh Co River suffers from severe seawater intrusion in the dry season (Vu et. al. 1991). However, the damage caused by the salinity problem in this area has not been managed or reported in detail.

Besides, with the impact of seawater intrusion in the dry season along the lower part of the rivers, high salinity soil has been reported to influence land cover change (Dinh and Haruyama 2002a, 2002b). The irrigation system operated mainly by tide power and the expanse of salty water cultivation had an effect on soil salinity of 


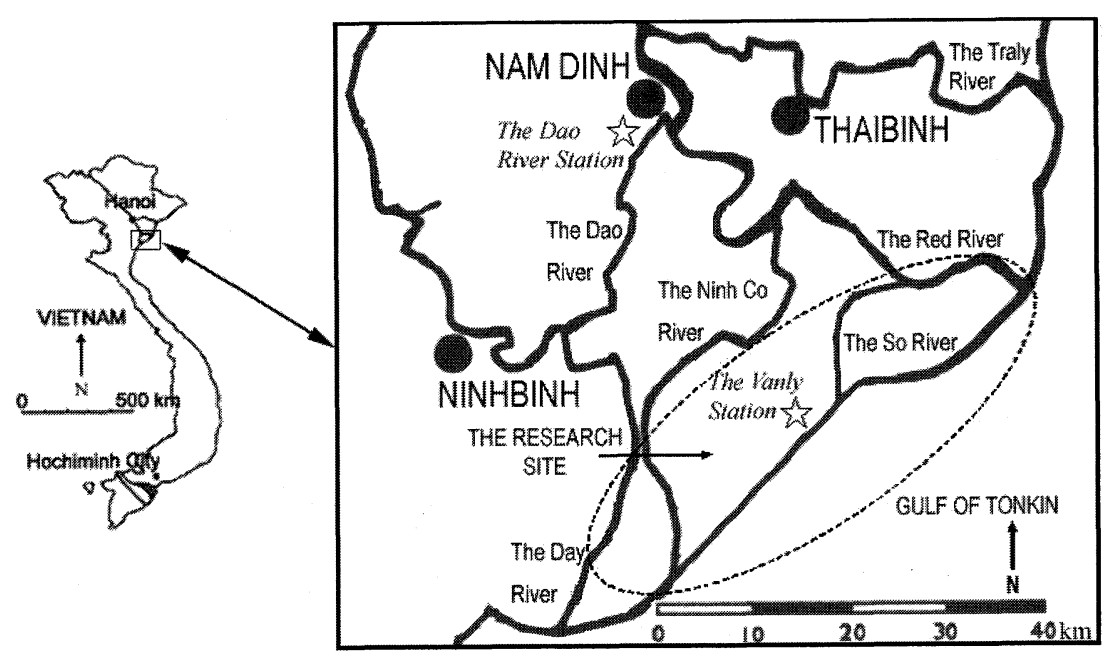

Figure 1. The research site-The coastal area of the Nam Dinh Province, The Red River Delta.

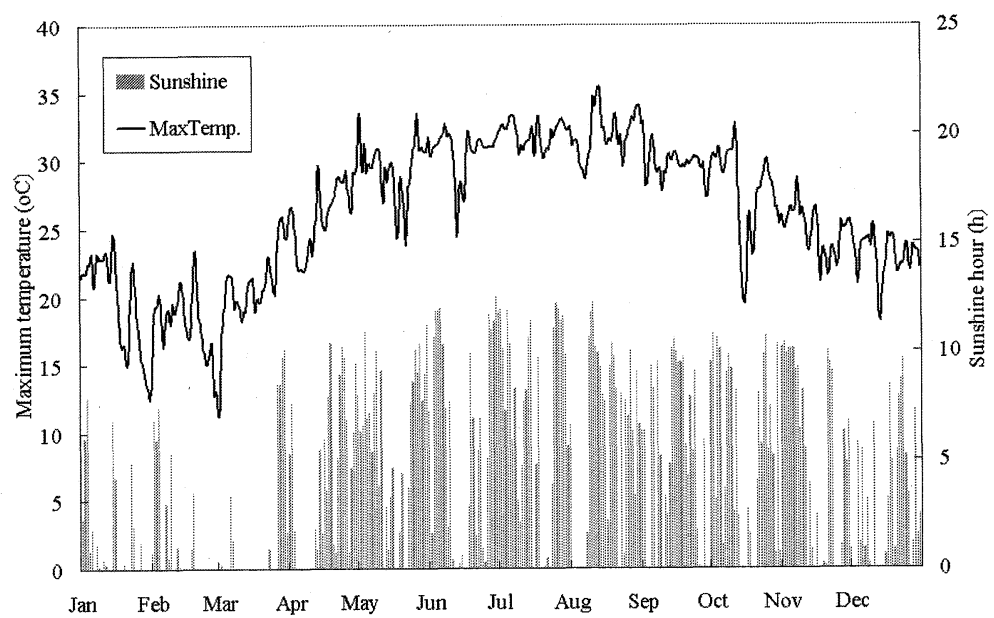

Figure 2. Maximum temperature and sunshine hour in the Van Ly Station, Nam Dinh Province-2000.

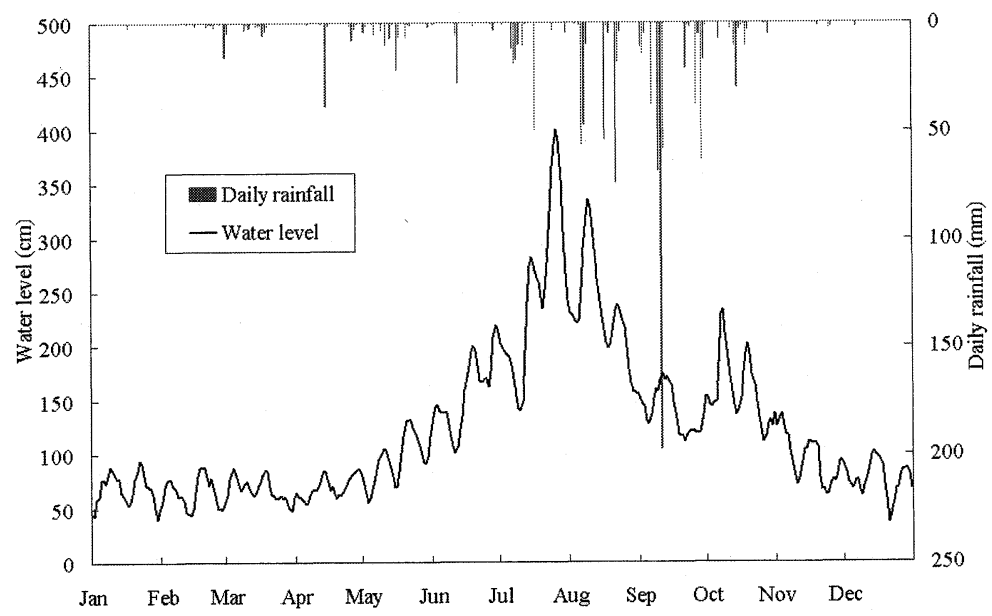

Figure 3. Daily rainfall in the Van Ly Station and water level in the Dao River, Nam Dinh Province-2000. 
paddy fields (Dinh et al. 2003). Despite the fact that the irrigation system is designed to manage seawater intrusion, insufficient attention has been paid to soil salinity problems along the coast of the Red River Delta.

In this study, salinity or total dissolved sodic (TDS) can be used to indicate the saltiness, which is caused by salt particles dissolved in irrigation water or absorbed on soil particle surfaces. The soil salinity and main ion concentrations absorbed on surface soil can be used to evaluate the salinity problem in paddy fields (Kim 1998). The concentration of ions in agricultural soil depends on such natural factors as soil particle size, chemical content of irrigation water, and human activities, including land use, fertilizer use, and irrigation-drainage systems (Bresler et al. 1982; Spark 1995).

To represent the existence of ions in soil and the relationship between soil and ions, a number of indexes have been calculated and applied in soil science. The Sodium Adsorption Ratio (SAR) has been used to characterize the sodium status of soil solutions. Petersen et al. (1996) mentioned that clay particles and organic matter are the main contributors to the cation exchange capacity (CEC). In the $\mathrm{SAR}, \mathrm{Na}^{+}$concentration related to the total concentration of $\mathrm{Ca}^{2+}$ and $\mathrm{Mg}^{2+}$ and SAR can be used to evaluate the cation adsorption selectivity of soil particles to $\mathrm{Ca}^{2+}, \mathrm{Mg}^{2+}$ and $\mathrm{Na}^{+} . \mathrm{Na}^{+}$and $\mathrm{Ca}^{2+}$ exchange selectivity differed according to clay minerals and clay content (Endo et al. 2002). The relation between the SAR and soil components has also been considered. Although direct relations between electrical conductivity and soil texture, or between the SAR index and soil texture, have not been clarified, the median average pore diameter of aggregates decreases when the SAR increases (Lebron et al. 2002).

To prevent the salinity problem, soil "washing" has been used for a long time in almost all saltaffected paddy fields in Nam Dinh Province. The salt particles are washed out from surface soil by irrigating the soil from 3 to 5 times before transplanting.

This study focuses on changes in salinity and in concentrations of main inorganic ions in top soil from 0 to $100 \mathrm{~cm}$ in depth along the coast of the Red River Delta in Nam Dinh Province. This study was designed to clarify the soil salinity and the main $\left(\mathrm{Ca}^{2+}, \mathrm{Mg}^{2+}, \mathrm{Na}^{+}\right.$and $\left.\mathrm{Cl}^{-}\right)$ion concentrations in the top soil of paddy fields, as well as the interactions between these ion concentrations and soil particles in different conditions of soil composition and land cover. The exchange selectivity between $\mathrm{Na}^{+}$and $\mathrm{Ca}^{2+}$ and $\mathrm{Mg}^{2+}$ has also been studied by considering the SAR value in the surface soil layer, which can be used to evaluate soil salinity.

\section{Methodology}

In this study, survey trips and samplings were carried out from August $28^{\text {th }}$ to August $31^{\text {st }}$, 2002 , in the flood season, during the growth period of rice plants and from February $22^{\text {nd }}$ to March $1^{\text {st }}, 2003$, in the dry season, after the transplantation period. Soil samples from paddy fields and shrimp ponds in Giao An (GA), Giao Thien (GT), Hai Phuc (HP), Nghia Lac (NL), Nghia Thang (NT), Hai Trieu (HT), Hai Ninh (HN), Nam Dien (ND) and Nong Truong Rang Dong (NTRD) villages were collected in the flood and dry seasons. Using portable boring equipment soil samples were taken to a depth of $100 \mathrm{~cm}$, in $20 \mathrm{~cm}$ sections at each of nine locations far from residential areas (Figure 4 and Table 1). The salinity of irrigation water in the sampled rice paddies was measured using portable equipment (DKK-TOA, CM-21M salinity and temperature measurers).

The process of soil analysis took place in the laboratory as follows (Figure 5). To measure soil $\mathrm{pH}$, there are three main methods: $\mathrm{pH}_{\mathrm{CaCl}_{2}}, \mathrm{pH}_{\mathrm{KCl}}$ and $\mathrm{pH}_{\mathrm{H}_{2} \mathrm{O}}$. Because all soil samples were agricultural soils, $\mathrm{pH}_{\mathrm{KCl}}$ was measured to limit fertilizer's influence on the accuracy of the $\mathrm{pH}$ value. Electric conductivity (EC) of the soil samples also has been measured and used to calculate the TDS values. The main $\left(\mathrm{Ca}^{2+}, \mathrm{Mg}^{2+}, \mathrm{Na}^{+}\right.$and $\mathrm{Cl}^{-}$) ion concentrations in the soil samples were analyzed (Jones 2001).

The SAR was used in this study to represent the existence of ions in soil and the relationship between soil and ions. The SAR is calculated by equation below: 


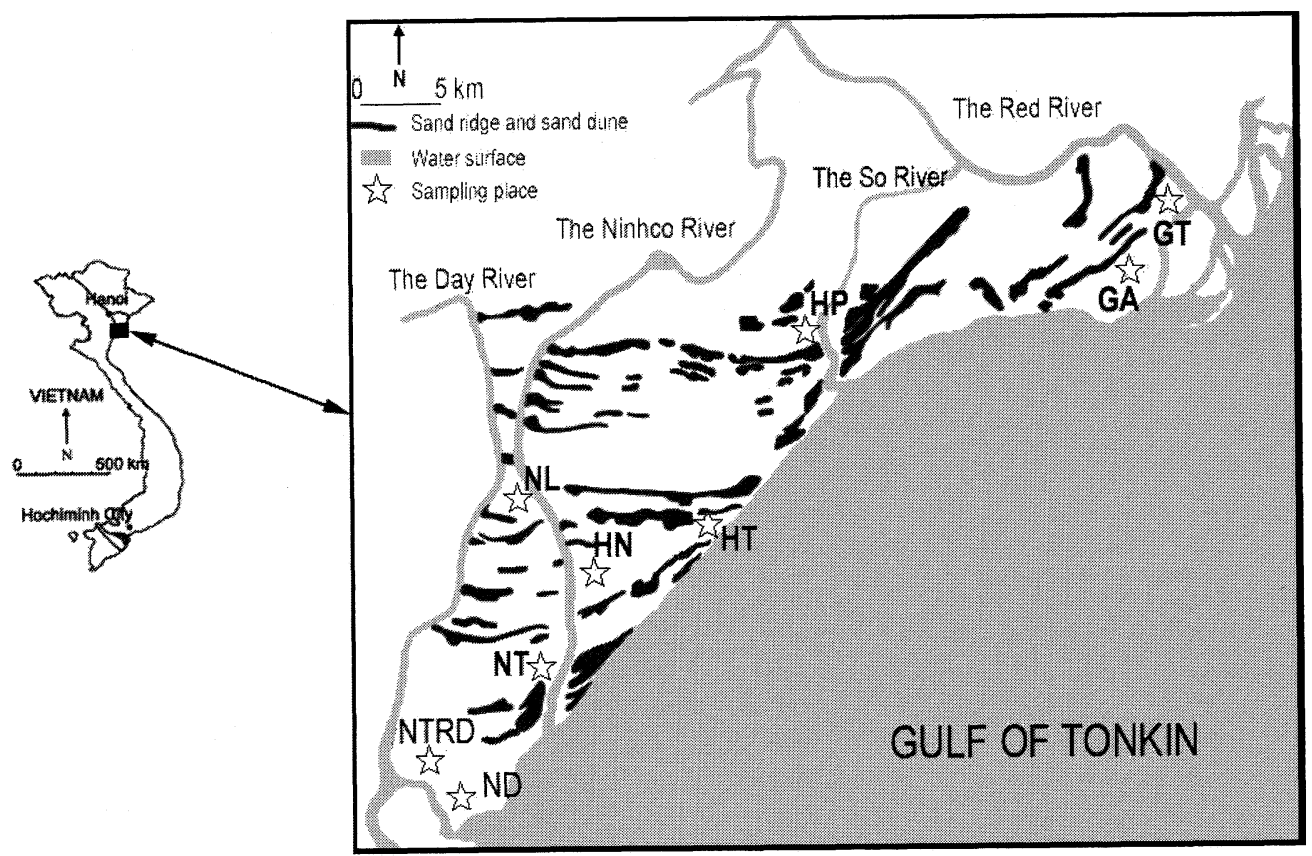

Figure 4. Soil sampling map.

Table 1. Name and location of the soil sampling places

\begin{tabular}{|c|c|c|c|c|c|c|}
\hline Name & Symbol & Place & Latitude & Longitude & Dry season & $\begin{array}{c}\text { Flood } \\
\text { season }\end{array}$ \\
\hline Giao An & GA & $\mathrm{R}$ & $20^{\circ} 15.289^{\prime} \mathrm{N}$ & $106^{\circ} 30.496^{\prime} \mathrm{E}$ & $\mathrm{x}$ & $\mathrm{x}$ \\
\hline Giao Thien & GT & $\mathrm{R}$ & $20^{\circ} 17.095^{\prime} \mathrm{N}$ & $106^{\circ} 33.195^{\prime} \mathrm{E}$ & $\mathrm{x}$ & $\mathrm{x}$ \\
\hline \multirow[t]{2}{*}{ Hai Phuc } & \multirow[t]{2}{*}{$\mathrm{HP}$} & $\mathrm{R}$ & $20^{\circ} 12.659^{\prime} \mathrm{N}$ & $106^{\circ} 21.024^{\prime} \mathrm{E}$ & \multirow[t]{2}{*}{$\mathrm{x}$} & $\mathrm{x}$ \\
\hline & & $\mathrm{P}$ & $20^{\circ} 12.305^{\prime} \mathrm{N}$ & $106^{\circ} 21.027^{\prime} \mathrm{E}$ & & $\mathrm{x}$ \\
\hline Hai Trieu & $\mathrm{HT}$ & $\mathrm{R}$ & $20^{\circ} 05.625^{\prime} \mathrm{N}$ & $106^{\circ} 15.925^{\prime} \mathrm{E}$ & $\mathrm{x}$ & $\mathrm{x}$ \\
\hline Hai Ninh & $\mathrm{HN}$ & $\mathrm{R}$ & $20^{\circ} 06.280^{\prime} \mathrm{N}$ & $106^{\circ} 13.676^{\prime} \mathrm{E}$ & $\mathrm{x}$ & $\mathrm{x}$ \\
\hline Nghia Lac & NL & $\mathrm{R}$ & $20^{\circ} 06.481^{\prime} \mathrm{N}$ & $106^{\circ} 11.740^{\prime} \mathrm{E}$ & $\mathrm{x}$ & $\mathrm{x}$ \\
\hline Nghia Thang & NT & $\mathrm{R}$ & $20^{\circ} 00.311^{\prime} \mathrm{N}$ & $106^{\circ} 10.537^{\prime} \mathrm{E}$ & $\mathrm{x}$ & $\mathrm{x}$ \\
\hline Nong Truong Rang Dong & NTRD & $\mathrm{R}$ & $19^{\circ} 58.521^{\prime} \mathrm{N}$ & $106^{\circ} 06.250^{\prime} \mathrm{E}$ & $\mathrm{x}$ & \\
\hline \multirow[t]{2}{*}{ Nam Dien } & ND & $\mathrm{R}$ & $19^{\circ} 58.018^{\prime} \mathrm{N}$ & $106^{\circ} 05.675^{\prime} \mathrm{E}$ & $\mathrm{x}$ & \\
\hline & & $\mathrm{P}$ & $19^{\circ} 58.543^{\prime} \mathrm{N}$ & $106^{\circ} 08.351^{\prime} \mathrm{E}$ & & $\mathrm{x}$ \\
\hline
\end{tabular}

R: Rice field; P: Shrimp pond

$$
\mathrm{SAR}=\frac{\left[\mathrm{Na}^{+}\right]}{\sqrt{\frac{\left[\mathrm{Ca}^{2+}\right]+\left[\mathrm{Mg}^{2+}\right]}{2}}}
$$

Soil particle size was analyzed using a Shimazu SALD-3000S grain-sizer. The composition of soil samples (percent of sand, silt, and clay) was cal- culated based on soil particle size obtained from analysis. The proportion of clay to sand and silt was calculated by the equation below:

$$
\text { Clay ratio }=\frac{[\text { Clay }]}{[\text { Sand }]+[\text { Silt }]}
$$




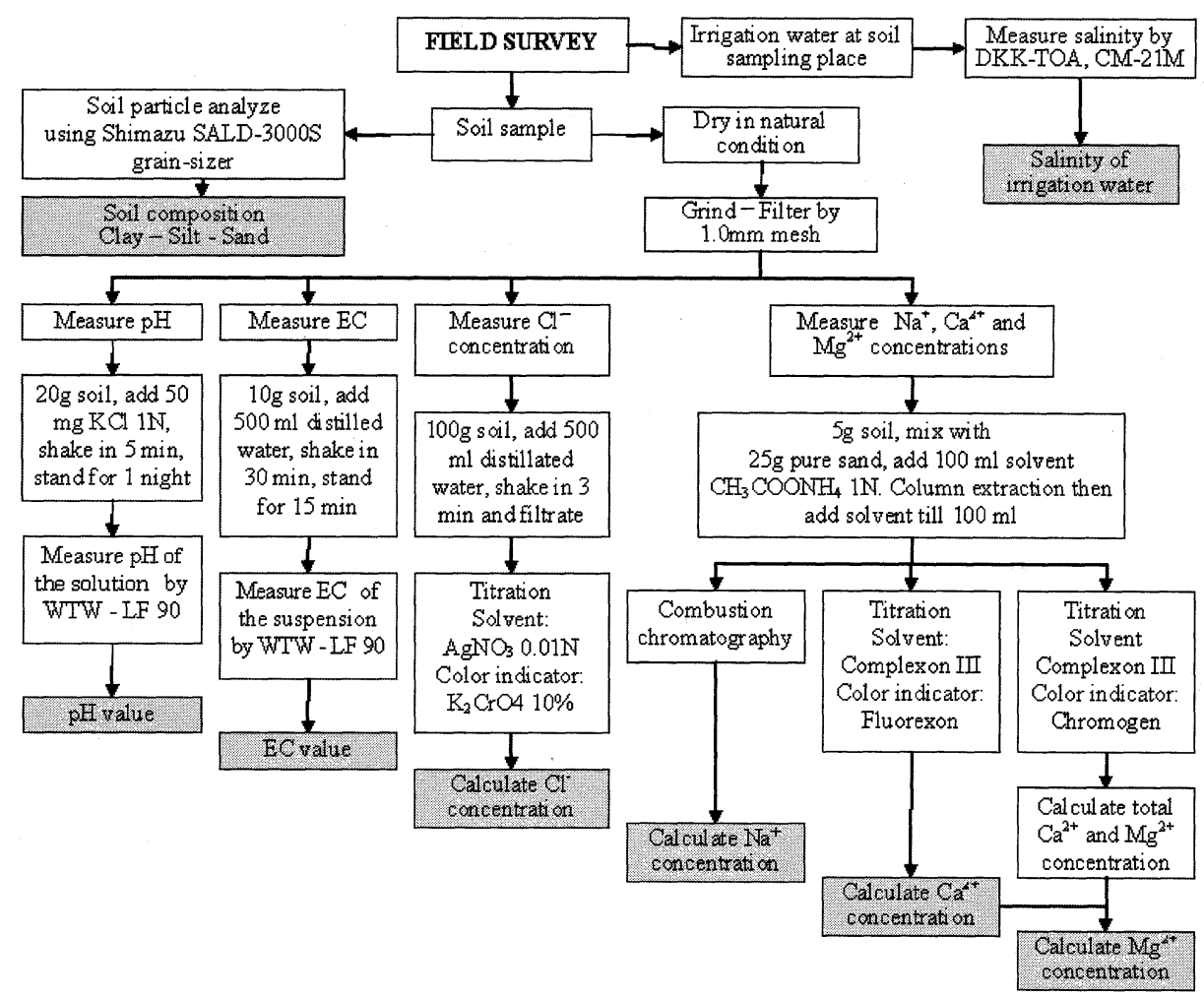

Figure 5. The soil analytical work.

Table 2. Salinity of irrigation water at the soil sampling places

\begin{tabular}{lcccccccccc}
\hline Location & GA & GT & HP & HT & HN & NL & NT & NTRD & ND \\
\hline Salinity (mg/l) & 400 & $\mathbf{5 0 0}$ & $\mathbf{1 5 0 0}$ & 300 & 200 & 200 & 300 & $\mathbf{7 0 0}$ & $\mathbf{9 0 0}$ \\
\hline
\end{tabular}

\section{Results}

\section{Salinity of irrigation water at the soil sampling places}

The salinity of irrigation water at 9 soil-sampling locations in the dry season is shown in Table 2. Four locations had salinity values in the irrigation water equal to or higher than $500 \mathrm{mg} / \mathrm{l}$ are GT, HP, NTRD and ND.

\section{Particle size of the soil samples}

All of the soil samples were subjected to particle size analysis. The content of the soil samples was mainly divided into three parts: clay, sand, and silt, depending on the particle size dis- tribution of each sample. The clay ratio was calculated using the values for clay, sand, and silt contents and Equation 2. Of the soil samples, the GT soil samples had the lowest clay ratio value, less than 0.1 , while other soil samples had clay ratios ranging from 0.2 to over 0.5 (Figure 6).

\section{Analysis of the top soil and the SAR}

All 90 of the soil samples collected in flood and dry seasons were analyzed in the laboratory. The $\mathrm{pH}_{\mathrm{KCl}}$ values ranged from mildly acidic to mildly alkaline in paddy field soil samples and were mildly alkaline in shrimp pond soil samples, as shown in Figure 7.

The $\mathrm{Ca}^{2+}, \mathrm{Mg}^{2+}, \mathrm{Na}^{+}$and $\mathrm{Cl}^{-}$concentrations of the soil samples collected in the flood season are shown in Figure 8 and the ion concentrations of 


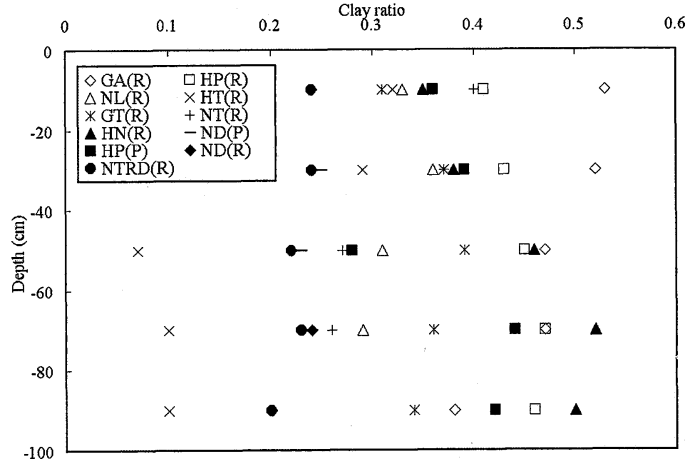

Figure 6. Clay ratio of the soil samples in the Nam Dinh Province.
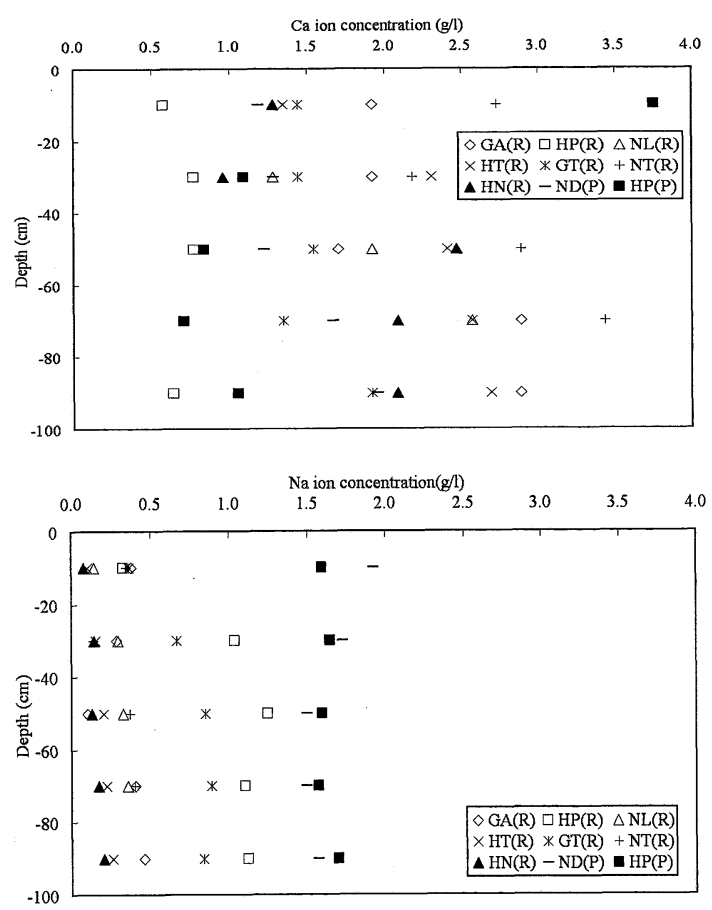

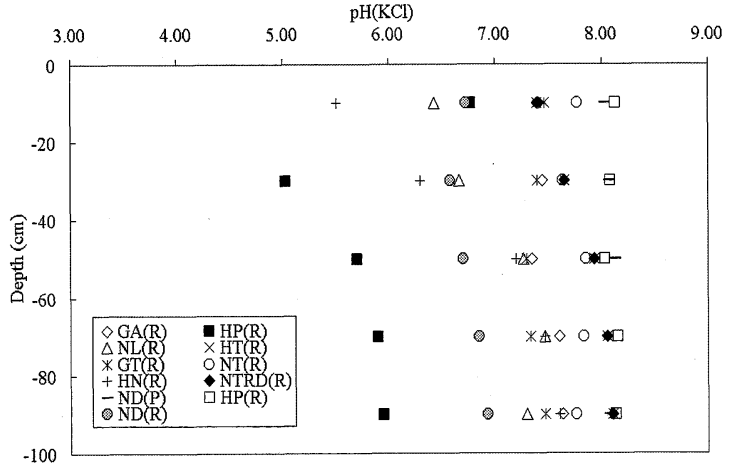

Figure 7. $\mathrm{pH}_{\mathrm{KCl}}$ of the soil samples in the Nam Dinh Province.
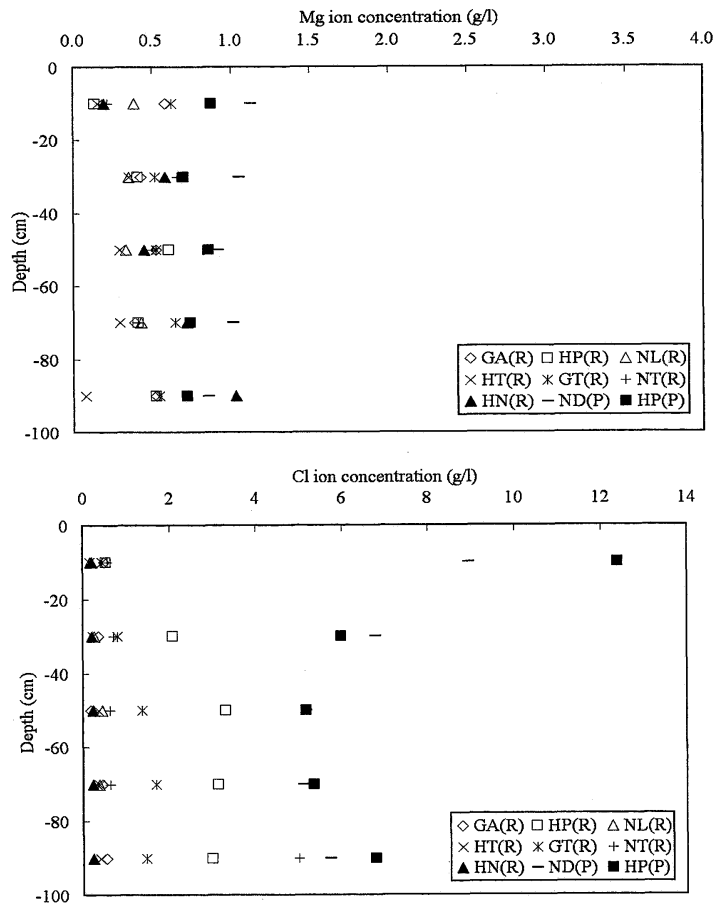

Figure 8. $\mathrm{Ca}^{2+}, \mathrm{Mg}^{2+}, \mathrm{Na}^{+}$and $\mathrm{Cl}^{-}$concentrations of the soil samples in flood season.

the soil samples collected in the dry season are shown in Figure 9. $\mathrm{Ca}^{2+}$ concentrations varied from $0.5 \mathrm{~g} / 1$ to $4.0 \mathrm{~g} / \mathrm{l}$ in both flood season and dry season, but the $\mathrm{Ca}^{2+}$ concentrations in the dry season were more consistent. $\mathrm{Mg}^{2+}$ concentrations were small, less than $0.5 \mathrm{~g} / \mathrm{l}$ in the dry season and around $0.5 \mathrm{~g} / \mathrm{l}$ in the flood season. $\mathrm{Na}^{+}$and $\mathrm{Cl}^{-}$concentrations appear not to differ between the flood and the dry seasons. Generally, $\mathrm{Ca}^{2+}$ concentrations were lower in top soil at shrimp ponds than in paddy fields, while the concentrations of $\mathrm{Mg}^{2+}, \mathrm{Na}^{+}$and $\mathrm{Cl}^{-}$in the top soil at shrimp pond were higher. (Figure 8 and Figure 9).

The TDS of the soil samples in the flood and dry seasons are described in Figure 10. In the paddy fields, the TDS of soil samples are slightly higher in the dry season than in the flood season. The TDS of soil samples was definitely higher in shrimp ponds than in paddy fields. The TDS was lower in the upper soil layer than in the lower layer in paddy fields, while the converse 

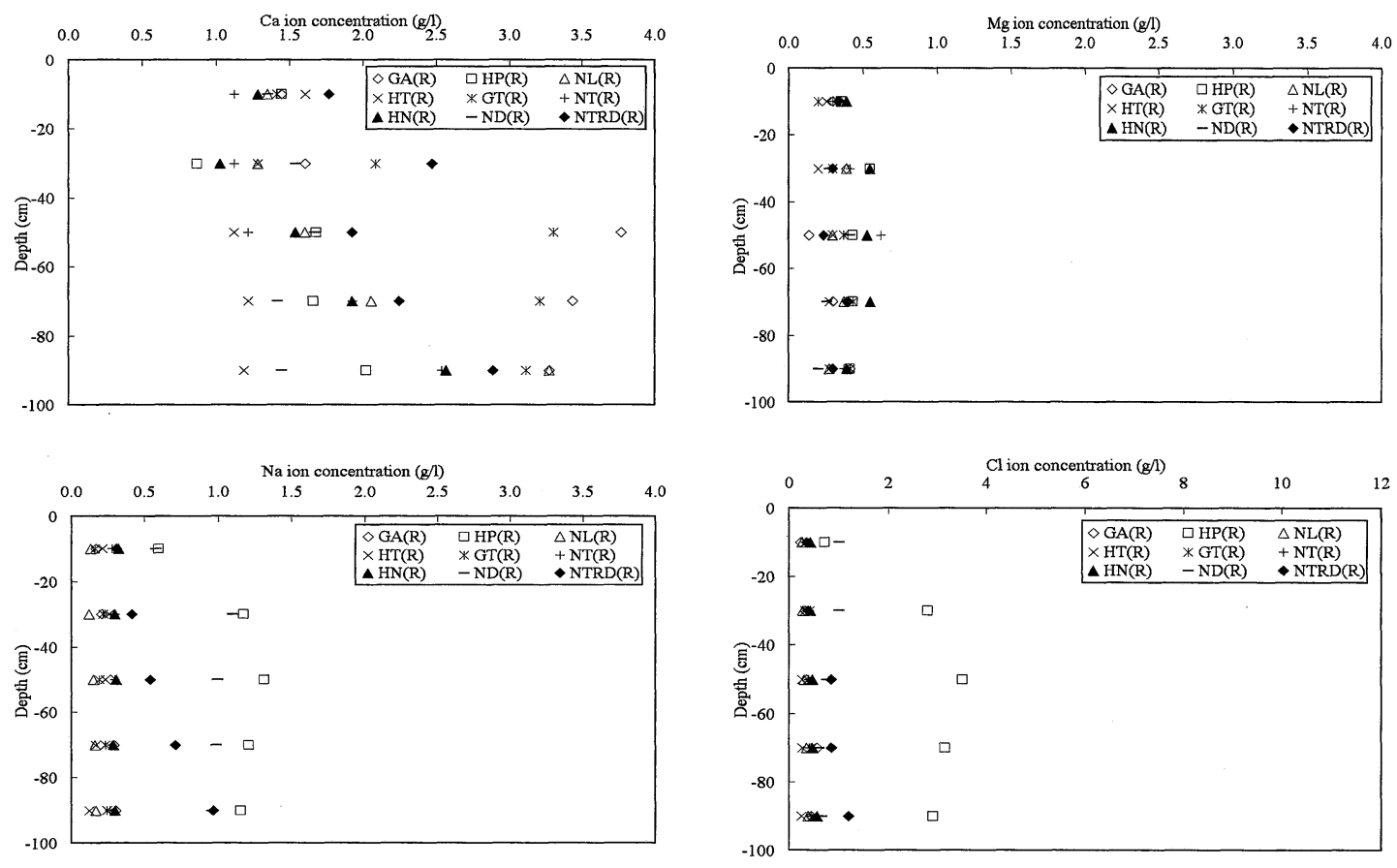

Figure 9. $\mathrm{Ca}^{2+}, \mathrm{Mg}^{2+}, \mathrm{Na}^{+}$and $\mathrm{Cl}^{-}$concentrations of the soil samples in dry season.

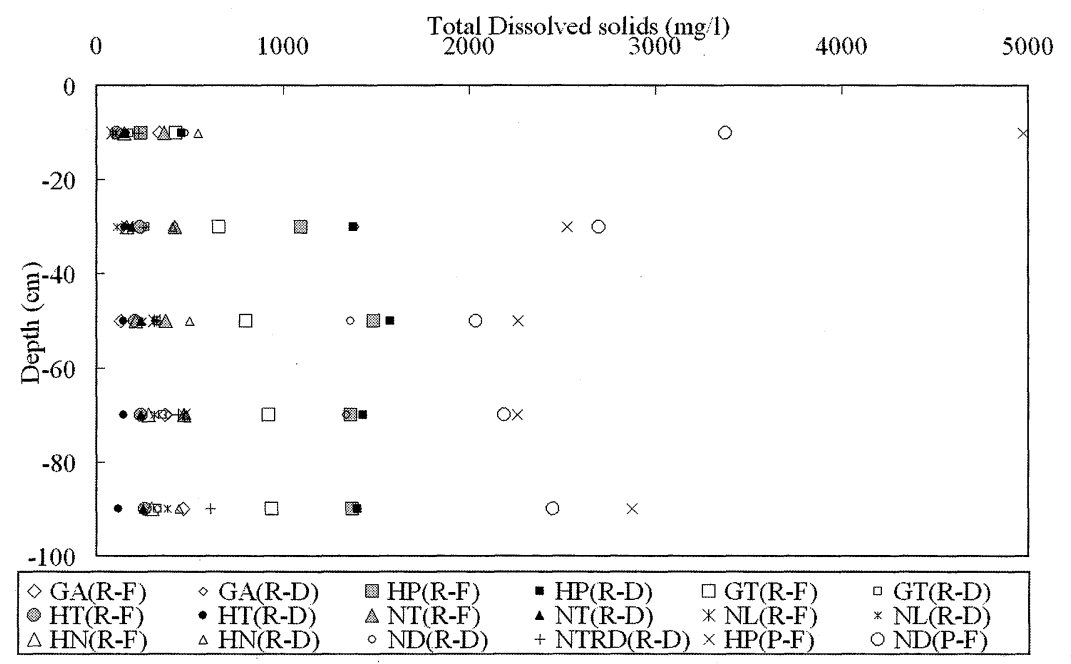

Figure 10. TDS of the soil samples in flood and dry seasons.

was true in shrimp ponds; this is caused by the washing process applied in paddy fields.

The SAR of the soil samples was calculated using the $\mathrm{Ca}^{2+}, \mathrm{Mg}^{2+}, \mathrm{Na}^{+}$concentrations and Equation 1, and are shown in Figure 11. Being affected by the concentrations of $\mathrm{Ca}^{2+}, \mathrm{Mg}^{2+}$ and $\mathrm{Na}^{+}$, the SAR values are different in the flood season and the dry season. However, the SAR values of soil samples in shrimp pond are still the highest, because of the relatively high concentration of $\mathrm{Na}^{+}$in soil samples of shrimp ponds. 


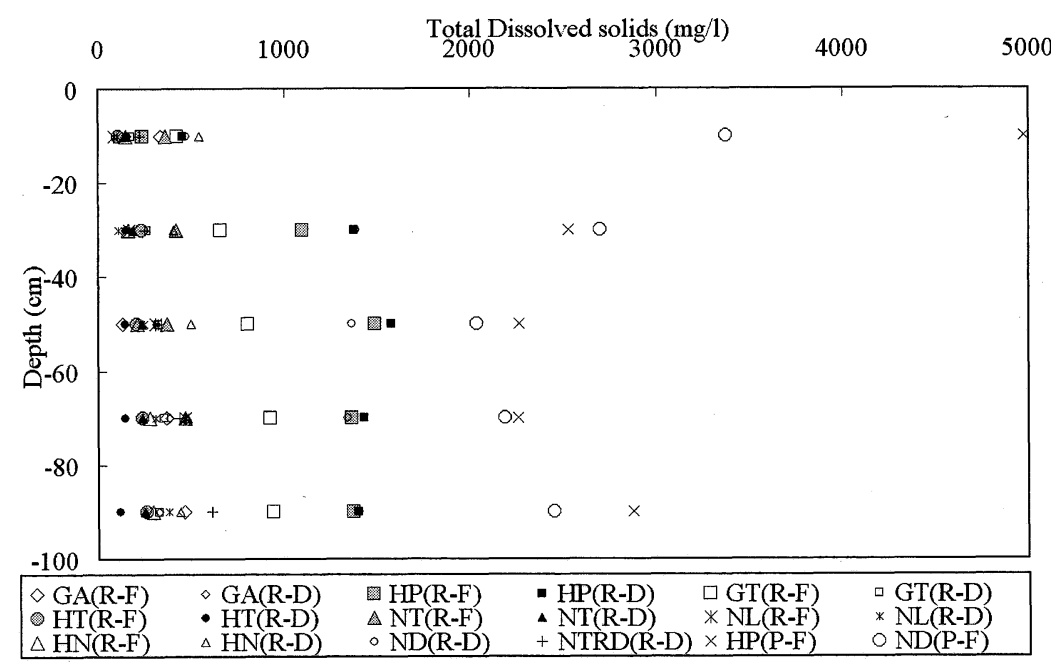

Figure 11. SAR of the soil samples in flood and dry seasons.

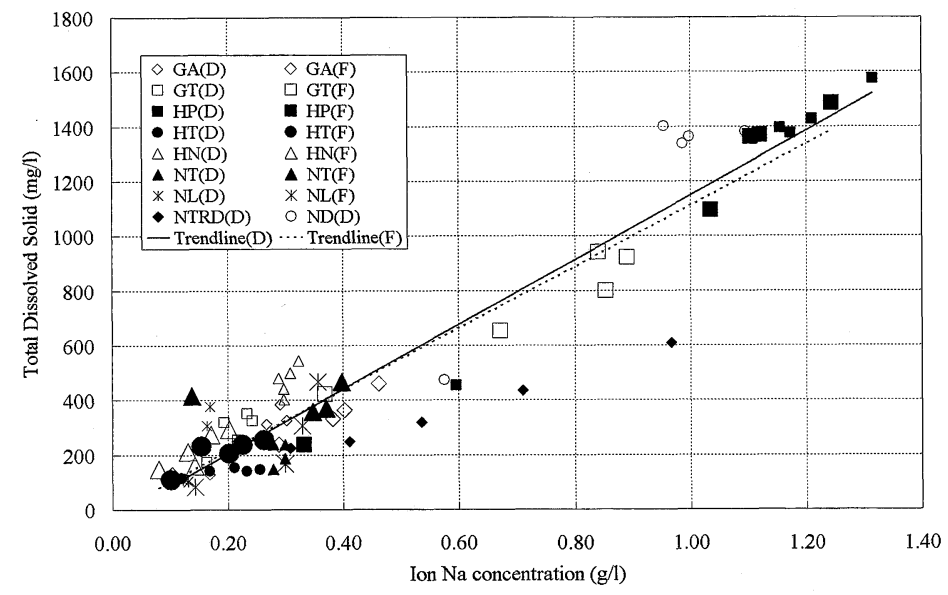

Figure 12. The relation between TDS and $\mathrm{Na}$ ion concentration of the soil samples in rice field-dry and flood seasons.

\section{Discussion}

\section{Relation between total dissolved solid and $\mathrm{Na}^{+}$concentration in $0-100 \mathrm{~cm}$ soil layers in paddy fields}

To consider the influence of salt water, TDS and $\mathrm{Na}^{+}$concentration were investigated. The TDS values in the soil samples from paddy fields increased when the $\mathrm{Na}^{+}$concentration increased (Figure 12). In both dry and flood seasons, TDS in collected soil samples ranged widely, from 100 to $1600 \mathrm{mg} / \mathrm{l} . \mathrm{Na}^{+}$concentrations also varied con- siderably, from approximately $0.1 \mathrm{~g} / \mathrm{l}$ to $1.3 \mathrm{~g} / \mathrm{l}$. However, the TDS value and $\mathrm{Na}^{+}$concentration of soil were slightly higher in the dry season than in the flood season. The relationships are described by the function (3) for the dry season and by the function (4) for the flood season:

$$
\begin{array}{ll}
Y=1182 X-33.025 & \text { with } R^{2}=0.8737 \\
Y=1124.2 X-11.89 & \text { with } R^{2}=0.949
\end{array}
$$

Generally, it is observed that high TDS soil has a high $\mathrm{Na}^{+}$concentration. Soil samples that have high TDS and high $\mathrm{Na}^{+}$concentration are representative of salt-affected paddy fields. In the flood season, the soil samples collected in paddy 


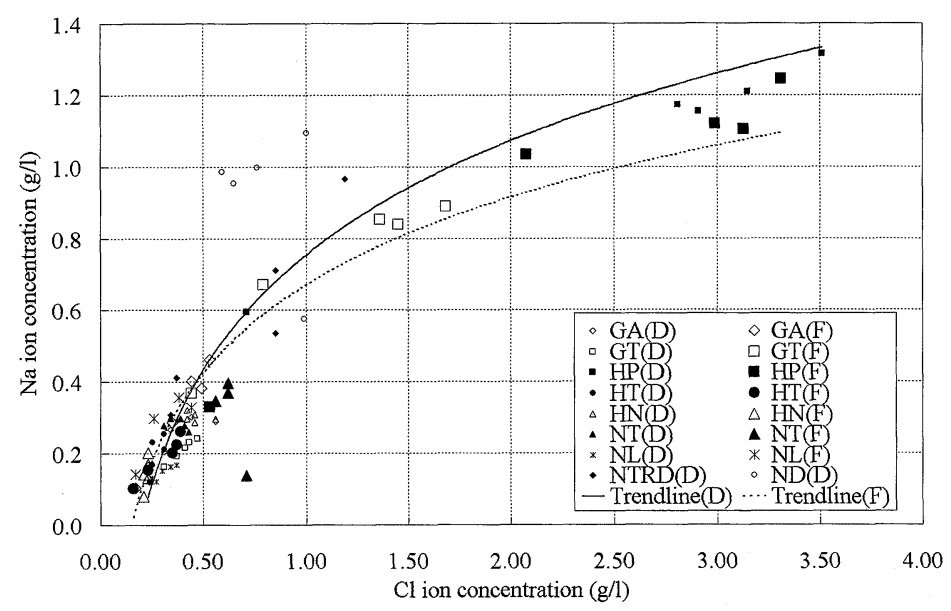

Figure 13. The relation between $\mathrm{Na}$ and $\mathrm{Cl}$ ion concentrations of the soil samples in rice field-dry and flood seasons.

fields at HP and GT had very high TDS values and $\mathrm{Na}^{+}$concentrations. The TDS and $\mathrm{Na}^{+}$ion concentrations in HP and ND were much higher in the dry season. The salinity of irrigation water was also the highest in HP, followed by ND, NTRD, and GT, GA (Table 2).

Comparison of the relation between TDS and $\mathrm{Na}^{+}$concentration shows a slight difference in the two trends in the flood season and the dry season. Although top soil at NTRD has quite high $\mathrm{Na}^{+}$concentrations, their TDS is not so high. It has been mentioned that $\mathrm{Na}^{+}$is more easily adsorbed by soil pores than $\mathrm{Ca}^{2+}$ and $\mathrm{Mg}^{2+}$. On the other hand, the clay ratio in NTRD varies from 0.2 to 0.25 (Figure 6 ) and the ion adsorption ability is lower in NTRD soil than in other soils.

\section{Relation between $\mathrm{Na}^{+}$and $\mathrm{Cl}^{-}$concentrations in 0-100 cm soil layers in paddy fields}

It is reported that $\mathrm{Na}^{+}$and $\mathrm{Cl}^{-}$concentrations are higher in salt-affected areas, where $\mathrm{Na}^{+}$concentrations rise to approximately $1.4 \mathrm{~g} / \mathrm{l}$, and $\mathrm{Cl}^{-}$ concentrations to $3.5 \mathrm{~g} / \mathrm{l}$. However, based on the analysis of this study, the relation between $\mathrm{Na}^{+}$ and $\mathrm{Cl}^{-}$concentrations in top soil appears to be logarithmic (Figure 13). $\mathrm{Na}^{+}$concentrations on soil surfaces are limited by the existence of $\mathrm{Ca}^{2+}$ and $\mathrm{Mg}^{2+}$ and by the $\mathrm{CEC}$, while $\mathrm{Cl}^{-}$concentrations can increase gradually and do not depend directly on the CEC. The functions of trend lines in both the dry season (5) and the flood season (6) are:

$$
\begin{array}{r}
Y=0.4612 \operatorname{Ln}(X)+0.7538 \quad \text { with } R^{2}=0.8206 \\
Y=0.354 \operatorname{Ln}(X)+0.67 \quad \text { with } R^{2}=0.8993
\end{array}
$$

Because all of the soil samples have been taken far from residential area, $\mathrm{Na}^{+}$and $\mathrm{Cl}^{-}$concentrations are not affected by residential wastewater, which is considered to have high concentrations of $\mathrm{Na}^{+}$and $\mathrm{Cl}^{-}$due to the use of detergents and salt in daily activities. Thus the high concentrations of $\mathrm{Na}^{+}$and $\mathrm{Cl}^{-}$demonstrate the impact of seawater intrusion on paddy fields in HP, GT and ND when considering the salinity of irrigation water in Table 2.

The relatively high $\mathrm{Na}^{+}$concentrations in soil samples from ND in the dry season differ slightly from the $\mathrm{Na}^{+}$and $\mathrm{Cl}^{-}$concentrations in the flood season compared with the dry season. The Day River's mouth has a high $\mathrm{Na}^{+}$concentration in the surface soil, since all of the samples collected at ND and NTRD had high $\mathrm{Na}^{+}$concentrations in proportion to salinity and $\mathrm{Cl}^{-}$concentration.

\section{The influence of the "washing method" on decreased soil salinity for rice cultivation}

The relation between $\mathrm{Na}^{+}$and $\mathrm{Cl}^{-}$concentrations in the soil samples was used once again to investigate this influence. Soil samples were divided into two layers: the $0-20 \mathrm{~cm}$ layer and the $20-100 \mathrm{~cm}$ layer in both the flood season (Figure 


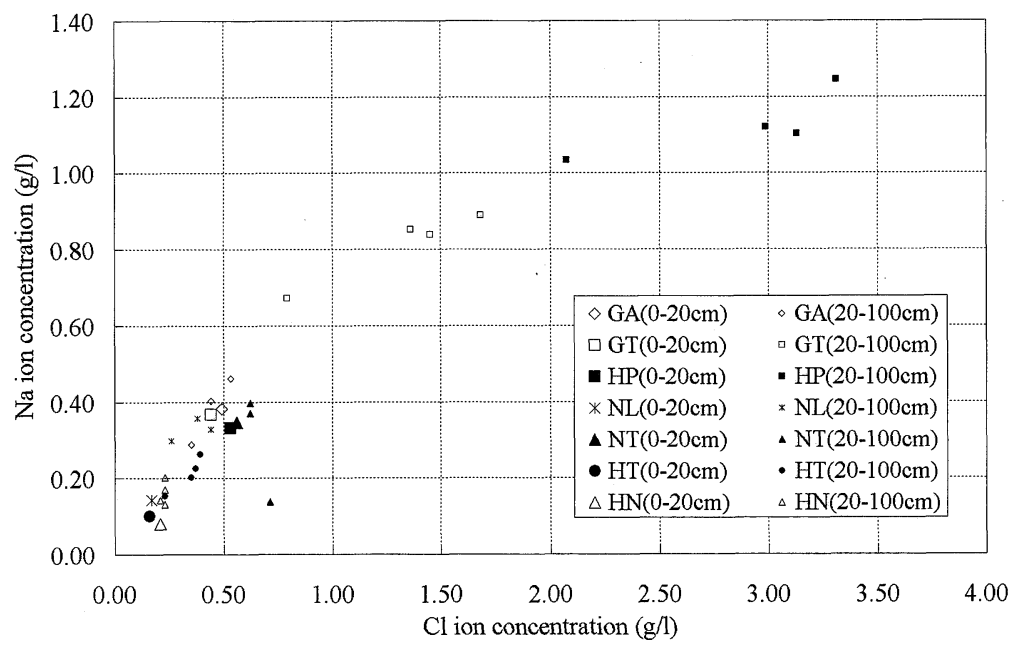

Figure 14. The $\mathrm{Na}$ and $\mathrm{Cl}$ ion concentrations of the soil samples in 0-20 cm layer and 20-100 cm layer in rice field-Flood season.

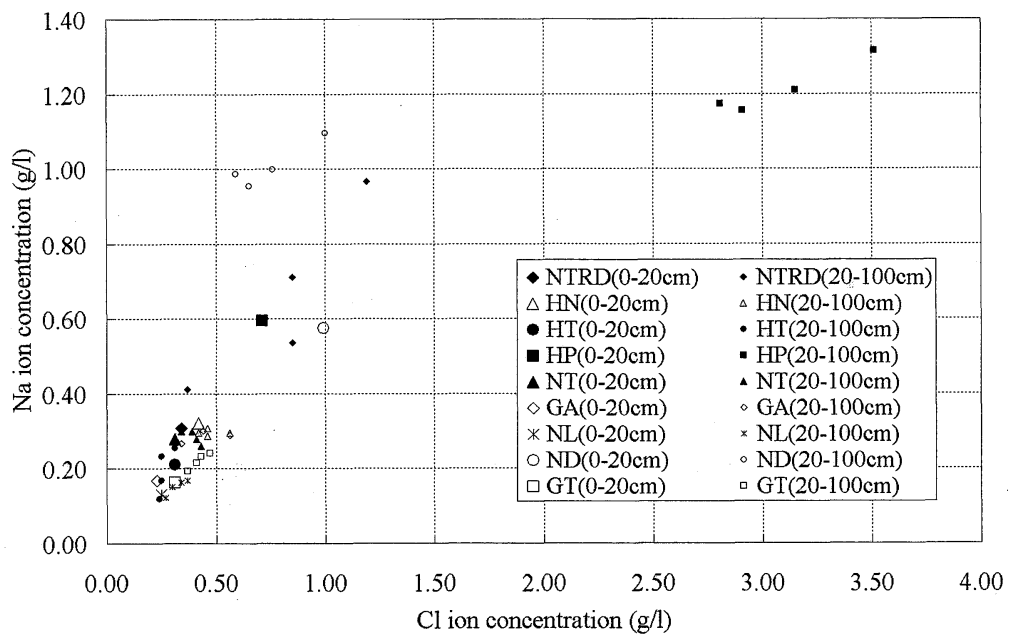

Figure 15. The $\mathrm{Na}$ and $\mathrm{Cl}$ ion concentrations of the soil samples in $0-20 \mathrm{~cm}$ layer and $20-100 \mathrm{~cm}$ layer in rice field-Dry season.

14) and the dry season (Figure 15). Comparison of the two layers shows that the $0-20 \mathrm{~cm}$ layer always has low $\mathrm{Na}^{+}$and $\mathrm{Cl}^{-}$concentrations, while GT and HP soil samples in the flood season and ND, NTRD, and HP soil samples in the dry season have high concentrations of $\mathrm{Na}^{+}$and $\mathrm{Cl}^{-}$in the $20-100 \mathrm{~cm}$ layer. The resulting $\mathrm{Na}^{+}$ and $\mathrm{Cl}^{-}$concentrations are quite low in almost all of the $0-20 \mathrm{~cm}$ soil samples, where the $\mathrm{Na}^{+}$ ion concentration is less than $0.4 \mathrm{~g} / \mathrm{l}$ and the $\mathrm{Cl}^{-}$ ion concentration is less than $0.6 \mathrm{~g} / \mathrm{l}$. The washing method used in paddy fields, especially in salt-affected rice paddies, reduces soil salinity in the surface soil layer in the flood season. The $\mathrm{Na}^{+}$and $\mathrm{Cl}^{-}$concentrations of $0-20 \mathrm{~cm}$ soil samples in salt-affected area such as HP and GT are diminished, although concentrations remain higher in the deeper layer. It can be said that HP and GT have a higher salt-affected potential than other places, but the effect of salinity can be controlled in the flood season (Figure 14). Irrigation and washing are also done in the dry season, when the $\mathrm{Na}^{+}$concentration is less than $0.4 \mathrm{~g} / \mathrm{l}$ and the $\mathrm{Cl}^{-}$concentration is less than 


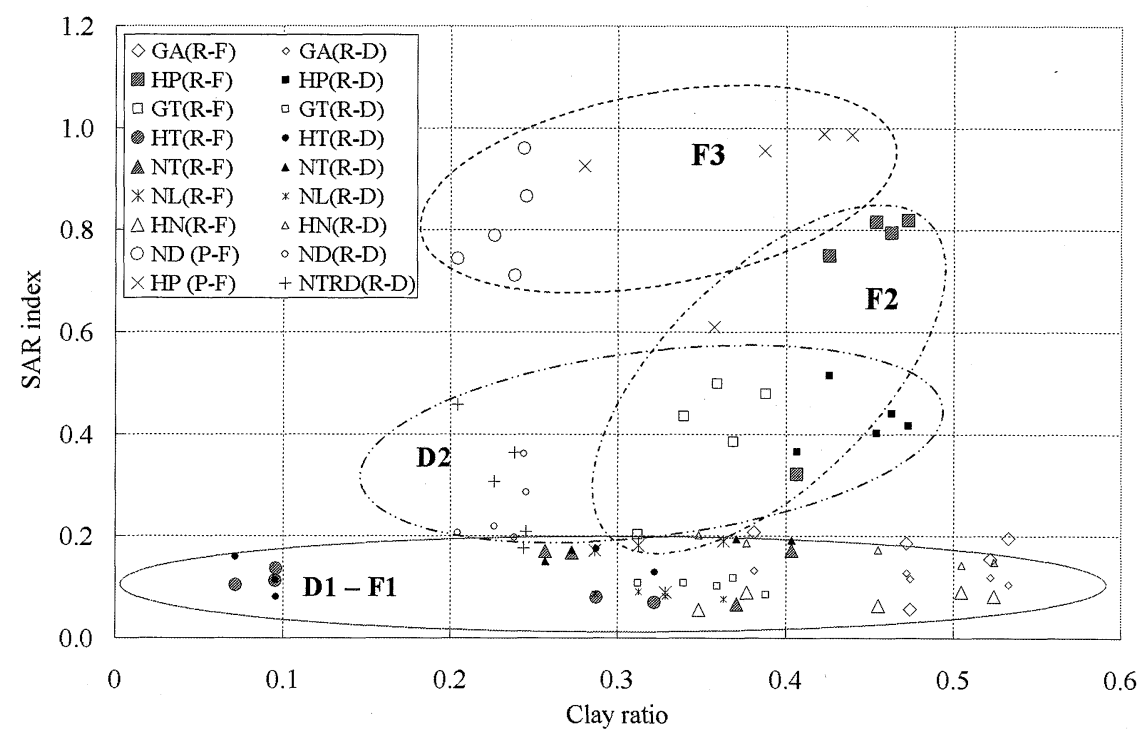

Figure 16. The SAR index and Clay ratio of the soil samples in flood and dry seasons.

$0.6 \mathrm{~g} / \mathrm{l}$. The $0-20 \mathrm{~cm}$ layer in HP and ND, where the salinity problem affects rice yields, has higher concentrations of $\mathrm{Na}^{+}$and $\mathrm{Cl}^{-}$(Figure 15).

\section{SAR and clay ratio of soil samples in the coastal area of the Red River Delta}

The relationship indicated by the SAR between these ion concentrations and soil composition in paddy fields and shrimp ponds was relied on heavily to describe the influence of land use on the chemical characteristics of soil in coastal agricultural land. The SAR under different conditions of land use, such as paddy fields and shrimp ponds was intensively investigated.

The relation between SAR and the clay ratio in soil samples was observed in different types of land use: shrimp ponds in ND and HP; high potential salt-affected paddy fields in HP, GT, ND and NTRD; and paddy fields in GA, NL, NT, HT and HN. Based on this classification, three groups can be seen clearly in the flood season samples: Group F1 includes paddy fields in GA, NL, NT, HT, and HN; Group F2 includes salt-affected paddy fields in HP and GT; Group F3 includes the top soil of shrimp ponds in ND and HP. Two groups can be identified in the dry season samples: Group D1 includes paddy fields in GA, GT, NL, NT, HT, and HN; Group D2 includes salt-affected paddy fields in ND, HP, and NTRD
(Figure 16).

SAR in shrimp ponds The value of the SAR varies from $0.6-1.0$ in the ND and HP shrimp ponds (Figure 16). The selective adsorption of $\mathrm{Na}^{+}$is higher than that of $\mathrm{Ca}^{2+}$ and $\mathrm{Mg}^{2+}$ in shrimp ponds compared to paddy fields. $\mathrm{Na}^{+}$is easily adsorbed on the soil particle surface and is easily washed out (Figure 8). The higher the clay ratio of a soil sample, the higher the SAR of the soil sample. This explanation can be confirmed by comparing the SAR and the clay ratio of ND and HP. In the soil samples of ND, the clay ratio was quite low, ranging only from 0.2 to 0.23 , while the clay ratio in HP ranges from 0.26 to 0.42 . One HP soil sample had a quite high clay ratio (0.35), but relatively low SAR (0.61). This soil sample belonged to the $0-20 \mathrm{~cm}$ soil layer of the HP sampling location. Normally, seawater is used for aquaculture and such water conditions in shrimp ponds as $\mathrm{pH}$ and the $\mathrm{EC}$ value are often controlled, depending on the variety and growth of shrimp. Inorganic calcium chemicals are used to maintain mildly alkaline conditionsgood eutropic and healthy conditions for shrimp breeding (Whangchai et al. 2004). Interviews by the author on the survey trips provided similar information. In the research site, calcium oxide $(\mathrm{CaO})$ and calcium hydroxide $\left(\mathrm{Ca}(\mathrm{OH})_{2}\right)$ were always used for this purpose. This may have caused an abnormal $\mathrm{Ca}^{2+}$ concentration in the 
top layer soil (Figure 8).

SAR in the highly salt-affected paddy fields The soil samples from salt-affected areas such as GT and HP in the flood season and NTRD, ND, and HP in the dry season had high SAR values. The relationship between SAR and clay ratio in salt-affected paddy fields in the flood season is shown in Figure 16. With higher clay ratios, soil samples in HP paddy fields had higher SAR values. In this group, SAR value ranged from 0.2 (the lowest measured in GT samples) to 0.82 (the highest measured in HP samples). A soil sample from the top surface layer of a paddy field in HP also gave a fairly low SAR. This suggests that the top surface soil layer is always more strongly affected by the washing process than the deeper soil layer is. This agrees with previous findings that the $\mathrm{Na}^{+}$concentration in the top surface soil layer is washed out by the washing process. In the dry season, the relation between the SAR and the clay ratio is similar. The clay ratio varies from 0.2 to 0.47 and the SAR varies from 0.15 to 0.52 . The clay ratio also seems, in the light of changes in the clay ratio and the SAR of the soil samples, to have a slight effect on the SAR.

$S A R$ in paddy fields In rice paddies, it is reported that a salinity of irrigation water over $500 \mathrm{mg} / \mathrm{l}$ may cause spotty stands of crops, uneven, stunted growth, and poor yields. In fact, the SAR of all the $0-20 \mathrm{~cm}$ layers at almost all sampling locations was very low, from less than 0.1 to 0.2 in both the flood and the dry seasons (Figure 16). Due to the impact of such soil improvement practices as washing, no soil sample had a SAR higher than 0.2 , although the clay ratio varied widely from 0.07 to 0.53 . The low SAR values suggest that $\mathrm{Na}^{+}$concentrations were much lower than the $\mathrm{Ca}^{2+}$ and $\mathrm{Mg}^{2+}$ concentrations. On the other hand, the SAR values of deeper soil layers $(20-100 \mathrm{~cm})$ are almost always higher than 0.2 in places that have high salinity in irrigation water: HP, NTRD, and ND (Table 2). The salinity of irrigation water at HP, NTRD, and ND are $1500 \mathrm{mg} / \mathrm{l}, 700 \mathrm{mg} / \mathrm{l}$ and $900 \mathrm{mg} / \mathrm{l}$, higher than $500 \mathrm{mg} / \mathrm{l}$, the maximum allowable salinity for paddy fields. Thus the SAR value could be used to consider the soil salinity in coastal paddy fields of the research area, where there is a high potential for salinity prob- lem. For any paddy field with a SAR of the surface soil layer higher than 0.2 , irrigation and washing should therefore be considered properly to prevent salinity problems.

\section{Conclusions}

This study investigated the surface soil layer from 0 to $100 \mathrm{~cm}$ in depth of paddy fields and shrimp ponds in Nam Dinh Province of the Red River Delta. The conclusions are stated below:

1. There is a linear relation between total dissolved solid and $\mathrm{Na}^{+}$concentration. Soil samples that have high TDS and high $\mathrm{Na}^{+}$concentration are representative of saline soil areas influenced by seawater. $\mathrm{Na}^{+}$and $\mathrm{Cl}^{-}$concentrations in soil samples also are related logarithmically. The $\mathrm{Cl}^{-}$concentrations increase gradually and do not depend directly on the cation exchange capacity of the soil. Soil washing of paddy fields influences surface soil salinity.

2. The most highly salt-affected paddy fields are Hai Phuc, Giao Thien, Nam Dien and Nong Truong Rang Dong. The soil samples from these paddy fields have the highest SAR values and are the most strongly affected by salinity in both the flood season and the dry season. Soil samples from paddy fields of Nam Dien and Nong Truong Rang Dong have high SAR values with considerable $\mathrm{Na}^{+}$concentrations.

3. Change in the SAR in different places and under different conditions of land use can show the relative selective adsorption of $\mathrm{Ca}^{2+}, \mathrm{Mg}^{2+}$, and $\mathrm{Na}^{+}$ions on soil particle surfaces, as well as the influence of seawater intrusion.

4. In coastal agricultural land, the SAR in the surface soil layer can be used to evaluate the influence of salinity. In this study, the SAR value 0.2 can be considered to represent a paddy field unaffected by salinity. For any paddy field with a SAR of the surface soil layer higher than 0.2 , irrigation and washing should therefore be considered properly to prevent salinity problems.

Further studies should be carried out to understand more clearly the mechanism of salinity problems in saline soils, the impact of high concentrations of $\mathrm{Na}^{+}, \mathrm{Cl}^{-}$, and other ions on agricultural activities, and responses by residents. The influence of salinity in the surface soil layer of cultivated land on inhabitants' life styles 
should also be investigated to clarify the complicated relationship between human activities and the changing natural environment.

\section{Acknowledgements}

The authors would like to express their sincere appreciation to Prof. Le Van Tiem and Dr. Nguyen Dac Hoan of the Agricultural Planning and Development Institute, Hanoi, Vietnam, for sharing their knowledge and generously cooperating during the authors' field trips and soil analysis.

(Received 1 March 2004)

(Accepted 24 July 2006)

\section{References}

Bresler, E., McNeal, B. L., and Carter, D. L. 1982. Saline and sodic soils. Berlin: Springer-Verlag.

Dinh, H. T., and Haruyama, S. 2002a. The salinity intrusion and soil salinity in the coastal area of the Red River Delta, Northern Vietnam. Proceedings of the General Meeting of the Association of Japanese Geographers 62: 122.

Dinh, H. T., and Haruyama, S. 2002b. The impact of salinity intrusion on land use change in the coastal area of the Red River Delta, Northern Vietnam A case study in Nam Dinh Province. In: Proceedings of LUCC-ISPRS Workshop 2002 on LUCC Contribution to Asian Environmental Problems. India, Hyderabad, December 2002, ed. K. S. Rajan, 29-30. Hyderabad: IGU.

Dinh, H. T., Haruyama, S., Funabiki, A., and Shida, K. 2003. The influence of irrigation system on salinity in surface soil of agricultural land in coastal area of the Red River Delta-Northern Vietnam. In: Proceedings of the General Meeting of the Association of Japanese Geographers 63: 277. Tokyo: The Association of Japanese Geographers

Endo, T., Yamamoto, S., Honna, T., and Eneji, A. E. 2002. Sodium-calcium exchange selectivity as influenced by clay minerals and composition. Soil Science 167(2): 117-125.

Haruyama, S., and Vu, V. P. 2002. Coastal change in the Southern Red River Delta. Geological Journal 111: 126-132.

Jones, B. J. Jr. 2001. Conducting soil tests and plant analysis. Florida: CRC Press LLC.

Kim, H. T. 1998. Principles of soil chemistry. Third edition-Revised and Expanded. New York: Mar- cel Dekker, Inc.

Le, B. T. 1997. Vietnam, the country and its geographical regions. Hanoi: "The World" Publishing House.

Lebron, I., Suarez, D. L., and Schaap, M. G. 2002. Soil pore size and geometry as a result of aggregatesize distribution and chemical composition. Soil Science 167(3): 165-172.

Matsumoto J., Nguyen, V. V., Cao, D. D., Nguyen, M. C., Le, N. T. and Tran, D. B. 2001. Climatic changes in the Red River Bàsin. In Long climate change and the environment change of the lower Red River Delta, ed. S. Haruyama, J. Matsumoto, Y. Sakurai, Q. D. Le, V. T. Le, and K. P. Le, 12-56, Hanoi: Agriculture publishing House.

Petersen, L. W., Moldrup, P., Jacobsen, O. H., and Rolston, D. E. 1996. Relations between specific surface area and soil physical and chemical properties. Soil Science 161(1): 9-21.

Spark, D. L. 1995. Environmental soil chemistry. San Diego: Academic Press, Inc.

Vu, T. C., Suphat, V., and Asaeda, T. 1991. Study on salinity intrusion in the Red River Delta. Coastal Engineering Journal, JSCE 22: 213-218.

Whangchai, N., Migo, V. P., Alfafara, C. G., Young, H. K., Nomura, N., and Matsumura, M. 2004. Strategies for alkalinity and $\mathrm{pH}$ control for ozonated shrimp pond water. Aquacultural Engineering 30(1): 1-13.

\section{Content of legend in equations and functions}

(1): $\quad\left[\mathrm{Na}^{+}\right]: \mathrm{Na}^{+}$concentration in millimoles per liter.

$\left[\mathrm{Ca}^{2+}\right]+\left[\mathrm{Mg}^{2+}\right]$ : Total $\mathrm{Ca}^{2+}$ and $\mathrm{Mg}^{2+}$ concentration in millimoles per liter.

(2): [Clay]: content in percent of clay in a soil sample.

[Sand] $+[$ Silt]: Total content in percent of sand and silt in a soil sample.

(3), (4): $\mathrm{Y}$ is the $\operatorname{TDS}(\mathrm{mg} / \mathrm{l})$ in the soil sample $(\mathrm{Y}>0)$.

$\mathrm{X}$ is $\mathrm{Na}^{+}$concentration $(\mathrm{g} / \mathrm{l})$ in the soil sample $(X>0)$.

(5), (6): $\mathrm{Y}$ is the $\mathrm{Na}^{+}$concentration (g/l) in the soil sample $(\mathrm{Y}>0)$.

$\mathrm{X}$ is the $\mathrm{Cl}^{-}$concentration $(\mathrm{g} / \mathrm{l})$ in the soil sample $(X>0)$. 